\title{
English Language Textbooks in EFL Education: Multicultural Identity of Singapore as Ex-British Settlement and New Asian Global City
}

\section{Saiful Anwar MATONDANG}

Universitas Muslim Nusantara Al Washliyah Medan, Indonesia

C) The Author(s) 2017

\begin{abstract}
Although the construction of Singaporean society was based on the ethnic categories of British Settlement and recognizes the Chinese, Malay, India, and other ethnicities, but the present cultural policy in Singapore followed and implemented the idea of Asian Values that Lee posited. A single identity ignores the rights of the citizens of multicultural Singapore. This research paper questions the legalization of Asian Values as a new ideology for integrating Singapore to global economy which creates some paradoxes. The state's idea to revive a sense of Chineseness in Singapore (i.e., establish 'Asian Values') via the establishment of neoConfucianism ethics and the institutionalization of Mandarin as the lingua franca is a political fact, but for multiculturalists, this policy brings some paradoxes of the multicultural identity of Singapore ; it is arguable both in national and global contexts. The paradox comes when Singapore is identified as a single identity that generated from neo-Confucian by the elites in the ruling party. An integrated policy is to recapture humanity and to motivate the attachment of collective memory, social justice, the environment, and future factors to cultural identity. At present the reality of Singapore, it sees that the global culture of consumerism and the domination of the state in shaping urban life ignore the integrative policy. Obligations of city planners to address the ethical and social justice proportionally are urgently needed. For the construction of the fair multicultural identity, Singapore should emphasize the new notion of spatial justice in urban planning.
\end{abstract}

C2017.All rights reserved

\section{ARTICLE HISTORY}

Received: 25/11/2016

Accepted: 22/03/2017

Published online: 26/04/2017

\section{KEYWORDS}

Singapore multicultural identity, global city, Asian Values, neoConfucianism

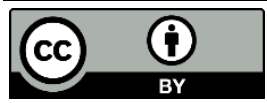

www.ijhsdr.com 


\section{Introduction}

As a city state, Singapore is growing to embrace Neo-Development City Planning. The preference of city planners in Singapore is to favor a cultural policy for global economic competition. In discussing the alternative futures city life, Douglass (2009:5) argues that Neo-Development City Planning tends to follow the Globopolis model-high global city status to enhance economic competition. Under the Globopolis model, a state with a top-down model regulates city planning and collaborates with corporations to enhance economic growth. To become attuned to a livable globopolis model, Singapore deployed a cultural policy termed 'Asian Values'. But before the state formalized Asian Values, it already had multicultural policy as national identity of Singapore. Asian Values brought a contradictive with multiculturalism. As a result, exclusivism and homogenized neo-Confucianism has served to neglect the local, hybrid, and transnational cultures. Taking Asian values as formalized cultural identity in Singapore into account, this paper aims to analyze the state policy of Singapore, and problematize constructed cultural identities in response to a global economy. By showing the rooted vernacular arts of multiculturalism, I would recommend three alternative cultural policies.

Problematizing the implication of a State-constructed identity and questioning what government call 'Asian Values', this paper argues that the current operation of cultural policy in Singapore tends to highlight the neo-Confucianism project. Addressing the forms of culture out of state policy that seems to oppose to the led-state centered arts also takes my attention. There is an increase production of local arts when the single identity proposed. The state's idea to revive a sense of Chineseness in Singapore (i.e., establish 'Asian Values') via the establishment of neoConfucianism ethics and the institutionalization of Mandarin as the lingua franca is a political fact, but for multiculturalists, this policy is arguable both in national and global contexts. The paradox comes when Singapore is identified as a single identity that generated from neo-Confucian by the elites in the ruling party. They want Singapore to project an image of a globopolis which "looks outward to global circuits of capital rather than inward to the ideas that residents might have about the livability of a city (Douglass, 2009)". Contesting the political motive, Goh (2009) disagrees with elites who seem to "sell Singapore as a global city to transnational capital" (68). Goh promotes Singapore as a transethnic society. In contrast to selected government culture to promote homogeneity, as if Singapore did not exhibit aspects of local culture, Goh supports the rights to all sections to activate local heritage. The Life Theatre Awards of Straits Times, for instance, inaugurates local theatre practitioners (Chong, 2011). The reason is that representations of citizen's cultural identity do not 
always follow and are not necessarily similar to that contingent with the State's cultural policy, and there is a need to set of Singapore identities based on the heritage such as the Peranakan Chinese (Babas), Anglo-Chinese, Malays and Tamils. For example, Vale (1992:48) posits, national identity must be cultivated for a long time in which the political and the national unit should be based on the collective identity.

\section{The Global Cities}

Before the analysis of a constructed cultural identity of Singapore is presented more detail, it is important to discuss global cities in terms of social construction and social hierarchy or ranking. From a theoretical viewpoint, globalization refers to first and foremost to economic pressures that undermine national economic autonomy and control (Schmidt, 1999:173). Largely, the discussion of global cities as the sites of global finance has attracted corporates. For example, Sassen's (2001) study reveals that the combination of spatial dispersal and global integration has created a new strategic role for major cities (London, New York, and Tokyo). These cities serve as: 1) points of concentrated command of the world economy; 2) key locations for service firms; 3) sites of production and innovation and, 4) markets of products and innovation (3-4). In her conclusions, Sassen states that global cities are the sites of stock exchanges, international banking and finance, multi-national corporations and foreign investment, and corporate service firms. Furthermore, Gertler (1997) asserts that globalization has typically been based on five closely interrelated assertions: 1) the increased flows of capital contributing to the spatial expansion of markets; 2) the process of interregionalization and internationalization of firm organizations, 3) the development of space-transcending technologies of transportation and communication, 4) the expanding internationalization of production systems, and 5) the liberalization of economic policies (46-47).

The competition among the world cities to be notified as the flow of global in terms of connectedness constructs the symbolic meaning of the buildings. Following John Friedmann's idea, Abrahamson says that, "[the concentration of high-rise buildings with large numbers of banks and companies] correspond[s] with the role of global cities as centers of the international flow of money, information, and commodities" (Abrahamson, 2004:24). The global cities of the North since 1980 and the developing countries since 1990 have been integrated into various world markets. Manufacturing, mining, and agriculture stimulate growth in the demand for producer 
services. As a consequence of globalization, "the growth of producer service firms based in New York or London or Paris can fed by manufacturing located anywhere in the world as long as it is part of a multinational corporate network (Sassen, 2002)". The formerly major industrial cities that were most able quickly and thoroughly to transform themselves into the new industrial mode became the leading global citiesthe centers of the new global system.

\section{Rankings of Global Cities}

The policy make of Singapore considers itself a global city and believes in social construction of global cities and gets attached the flow of global finance is very important. Some scholars) criticize the way of measuring the hierarchy of cities in global economy, but for the leaders of cities, it is very vital being ranked as global cities. As a result, the competition among the cities to attract the global finance and multinational companies since 1990 had increasingly affected the way of looking at the functions of cities in Asia. King (2004) points out that the social implications of skyscrapers have contributed to an identity in line with that of a modern city and corporate power. Icons associated with world cities, such as tall skyscrapers, emerged in and expanded from New York and London to Asia. These new towers in Asia not only symbolize the sense of a global economy and global political power, but also help transform Asian cities from the third world into the first (17).

Although many arguments have been critical of the ranking of global cities, the studies of the interconnectedness of global cities with the flow of capital and network hierarchy, some state policies tend to embrace a global economy ideology. Cities in Asia, for example, reflect the ranks of global cities and reform public policies to attract corporations to get global financial opportunities, and create an image as global cities. The center of the Globalization and World Cities (Ga WC), where Taylor with his team presents a typology of intercity linkages, is constructed based on the producer services. This idea takes the attention of major cities. Taylor et al. mentions that cities are the objects of the study and the subjects are the firms. It aggregates the four sectors that contribute to defining the different levels of world cities. A space of transnational transactions is always crucial to the development of a modern world system, because the contestation of various ideas that shapes cities are appeared. Manuel Castells' work on "network societies" describes a space of flows existing at several levels starting with the basic electronic infrastructure; the world city network represents on the higher levels of spatial organization (Taylor et al. in Sassen, 2002). Beaverstock and Taylor (year) have also developed a corporate,

Int.J. Hum. Soc. Dev. Res.

Volume 1, № 1, 2017.41-54 
service-derived categorization ('Alpha', 'Beta', and 'Gamma' world cities) for different types of global cities. Alpha world cities, those which achieved a score of 10-12, are London, Paris, New York, Tokyo, Singapore, Los Angeles, Milan, and Chicago Beta world cities scored from 7 to 9 are San Francisco, Sydney, Toronto, Zurich, Brussels, Madrid, Mexico City, Sao Paolo, Moscow, and Seoul. Gamma world cities include Amsterdam, Jakarta, Kuala Lumpur, and Manila. The last category is evidence of world city formation like Auckland, New Delhi, Rio de Janeiro, and Helsinki (Sassen, 2000:99-102).

A significant critique of ranking global cities is based on objections to AngloAmerican hegemony links. Olds and Yeung (2004), for instance, warn that "the Anglo-American bias with respect to the production of knowledge on global cities also mirrors the general bias in academia with the vast majority of published (and high-impact) authors based in North America and Western Europe, including in development-oriented disciplines like Economics, Geography, Sociology, and Political Science" (page number). This method is criticized because it only focuses on the London-Located Global Firms (LLGFs) data. Additionally, Sassen analysis shows that the central components of the producer services category are a range of industries with mixed business and consumer markets, including insurance, banking, financial services, real estate, legal services, accounting, and professional associations (Sassen, 2000). They do not take into account the fact that all of these cities are the outcome of a wide range of processes, all of which are shaped by state and space.

Global cities normally function as key locations for finance and specialized service firms that gradually replace manufacturing as their leading sectors. Global cities are the combination of spatial dispersal and global integration. In its evolutionary process, Singapore is linked to principle global cities (London, New York, and Tokyo) in terms of capital flow and services. The question for Singapore is rather more complicated. Although it stands out for its port services and involvement in facilitating international trade and the worldwide flow of goods (from 2007 until 2011, Singapore's average quarterly GDP Growth was 6.36 percent reaching an historical high of 39.90 percent in March of 2010), Singapore's position as a global city is still contested. This is equally surprising as Singapore has a highly developed and successful free-market economy and enjoys a per capita GDP higher than that of most developed countries.

If the measurement method of ranking global cities is questionable, the representation of Singapore as the site of global business activity (i.e., a ranking of 10 in Taylor et al. (2002) and 7 in Kearney (2010)) need more analysis. This ranking 
recognizes Singapore as the place of a number of international conferences, flow of goods (air and port), and capital markets, but the question about who initiated those activities is left unaddressed. This is especially true as Singapore links to a number of companies among the top 40 global service firms, and a number of global companies have operational offices or headquarters in Singapore (Koh, at all 2002).

\section{Asian Values from Singapore Perspective}

The national identity of Singapore espoused by the government according to Lee Kuan Yew is Asian Values, an idea which is directly linked with Chinese Confucian values. Confucian teachings focus on qualities such as hard work, an emphasis on education, pragmatism, self-discipline, familial orientations and collectivism, and they have been regarded as key cultural factors for economic growth (Velayutham, 2007:55). Although the construction of Singaporean society recognizes the Chinese, Malay, India, and other ethnicities, the cultural policy in Singapore followed and implemented the idea of Asian Values that Lee posited. A single identity ignores the rights of the citizens of multicultural Singapore. By legalizing Asian Values as a new ideology for integrating Singapore to global economy creates some paradoxes. Asian Values are not rooted on the multicultural society of Singapore, as what Yew argues; "spaces do not accommodate the differences of the people and cities become indifferent to the needs of more groups of citizens (Yew, 2004:223)". Consequently, the spatial hegemony of state is apparent when evaluating the Singaporean effort to gain status as a global city at the expense of existing local practices. The cultural policy is principally implemented to accommodate a selected group of talented (and not necessarily local) people that is being cut off from local, blended, hybrid and Western characters. According to Vasil the core of Asian Values is a Confucian ethic in which hard work, thrift, and sacrifice as a role model (Vasil, 1995:78).

Lee's ambitious idea to have formalized Asian Values as a national ideology and apply them in schools, work places, and homes is made apparent in State policy. How well this policy runs with the age of global migration that "requires particular forms of cultural capital, which aspiring global cities seek to develop" (Kim, 2001) is questionable. At an operative level, a global city deals with three strategic orientations: "a people-oriented strategy, a product-oriented strategy, and a placeoriented strategy" (Kim, 2001 in Kong 2007).

Int.J. Hum. Soc. Dev. Res.

Volume 1, № 1, 2017.41-54 
The question of accommodating those strategies within Confucianism is an ever-growing discussion. Some scholars (e.g., Clammers 1998; Velayutham 2007; Vasil 1995; McCharty 2006; and Chong 2011) suggest that elites use Asian Values for to justify state control over pluralism. Their studies reveal that the elites have reinvented neo-Confucianism as Asian Values as grounds for controlling the opposition groups and dissenting opinions that distract the attractiveness of Singapore as a global city. Moreover, this policy is legitimizes the authoritarian rule already in place in Singapore, a view held by Velayutham (2007:55). Velayutham (2007:62-67) finds several motives for instantiating Asian Values in Singapore detailed below:

1.Maintaining PAP (elite) Power; the government rejects pluralism and deemphasizes liberal values and individual rights.

2.Imperative Economy: Asian Values function as buffer zone against social changes trend that halt the booming economic process.

3.National Identity: Asian Values become a collective identity-affective values of 'we-ness' or shared values.

In contrast to state policy, some scholars see that Singapore as a city state is constructed as a locus of power for elites which ignore the inherited vernacular cultures and does not recognize the culture of the English-educated middle class. The state enforces a new culture by retracing ancient Confucianism. The State in reality creates and promotes many projects that revive the Chineseness of Singapore as a cultural weapon to counter the liberalism and political pluralism brought by the English-speaking middle class and the local vernacular culture. By embracing globalization through Asianization, it is questionable as to whether Singapore's image would be fitting of a global city and supports a culturally enriched lifestyle if the Asian Values are applied.

Singapore ruling elites determines the development planning. Dale (1999) focuses on the Planning History of Singapore and indicates the paternalistic model of Singapore. He finds that Singapore is a neo-patrimonial state which does little to promote competitive politics and a pluralistic democracy. Also, Dale (1999) demonstrates that a development policy starts from the "elected government to its bureaucracy, composed of administrative departments and statutory boards (the HDB, URA, and others)" (page number). Following Wang's rejection of the neo-Confucian ethics as the main factor of economic growth in East Asian countries and Singapore, Dale argues that it was the penetration of a Western political economy that provided the conditions for the fast-growing economies. Singapore's international economy, 
based on Dale's analysis, is vulnerable and the government still needs to create a city state as a site of global finance by stressing the importance of a paternalistic system.

Clammer (1996: 156) argues that the trend in Singapore social policy is directed at the enhancement of Chinese primacy - the glorifying of traditional Chinese culture. Singapore's effort in creating a new universality based on neoConfucianism, other than Western cultures, is challenged by the multiculturalists. Vasil (1995: 115-120), for instance, highlights three reasons Singapore continues the process of Asianization, by pointing out the state's pragmatic view; Policy leads to stop the loss of highly -educated and skilled citizens, maintains a stable political order within the Chinese traditional and restores the family system.

\section{Asianizing Singapore}

Although a global city tends to develop cultural diversity, Singapore prefers to Asianize Singapore where Confucian ethics in response to global economy. Many ideas have been addressed to state for reconsidering the Asianization policy in Singapore. From a local perspective, Lim (2005) argues that it is necessary to gain the effective urban spatial justice implemented by providing "more sites for popular local performance and festivals at affordable prices for everyone" (28). Asian values result in a policy of cultural homogeneity in Singapore that is characterized by a strong state; a singular identity consisting of one language and one uniform culture (Lim, 2005:14). Furthermore, examining the content of Lee's Asian Values rhetoric is undertaken by McCharty (2006). This study assesses the degree of justice and discusses Confucianism as a means of preserving a regime which allows political leaders to defend the accusations of human rights violations (4-5). McCharty further argues that "the Confucianism values promoted in Lee's Asian values rhetoric emphasized order and stability above else. A good Confucian family, it followed, should provide the kind of stability whereby its members would not question a leader's authority" (88). The State implements a firm policy direction and social stability to sustain economic growth. This steady leadership creates a family that should respect authority, work hard, and keep silent. According to Hui (1997: 12-13), in Singapore the power elites generally implement developmental model to boost economic growth and professionals are sponsored and co-opted by the government. In turn, the professionals are controlled to the development policies operated to support the ruling elites. The domination of strong, cohesive and homogeneous power elites characterizes ideology, and development objectives.

Int.J. Hum. Soc. Dev. Res.

Volume 1, № 1, 2017.41-54 


\section{Dissimilarities between a Confucian Idealistic Society and Modern}

\section{Singapore}

A traditional Chinese society is substantially different from that of modern Singapore. The flow of power in Singapore is structurally generated from elites to civil bureaucrats and politicians, then to selected professionals and intellectuals. But military and business elites are not part of power structure (Hui, et al., 1997:12). By comparing traditional Chinese society to the modern society of Singapore, Chinkeong (1992:24-27) details three differences between the Singapore society and the Confucian's idealistic society. Firstly, Chinese stratifications in society traditionally have four classes (scholars, agriculturalists, artisans, and merchants), but Singaporeans are mostly immigrants who work as laborers and merchants. Secondly, in China there is the presence of extended lineage, gentry, and state powers as pillars and sanctioning institutions of Confucianism, but urban migrants in Singapore have not developed a common identity. The Chinese communities in Singapore mostly identify themselves based on their great parents' origin hometowns and dialects such as Baba, Hokkien, Cantonese and Hakka. Finally, the Confucian culture at its grassroots operational level stressed personal advancement and family welfare. In contrast, the commercial considerations gave rise to competition and cooperation in modern Singapore society.

Although, the knowledge-based economy of Singapore is linked to international transportation and global tourism as Yah said, (2009:8), to some degree the Singapore middle class then depends on the state for employment and, much of them feel anxious, neuroses. Now this kind of behavior is called kiasuism -feeling of raid of losing (Yun, 2001: 2000). The lack of interest in public affairs highlights the weakness of middle-class cultural identity. Singapore functions as a mediator between hyper-global cites in which the middle class is coopted for "both attracting in material and non-material flows, and in functioning as a command and control centre for the flows and networks" (Olds and Yeung, 2004: 489). It is necessary to redress the way in which Singaporean cultural identity is constructed. National identity should facilitate opportunities for social networks and cultural meaning for all citizens, not just those that ascribe to neo-Confucianism. 


\section{Fluidity of Cultural Identity as Spatial Justice}

Considering cultural identity and postmodernism, Lim (1995), Ling (2004) and Terence Chong (2011) propose a future model for cultural planning in Singapore. Cultural identity, for William Lim, is continuously constructed, always fluid and plural. Chong sees the tension inherent in identity formation. English-language theatre deliberates the issue of national identity and spaces that the state repressed (Chong, 2011: 67). In the future, there needs to be a process of remaking the privileged official statism in the current national cultural identity of Singapore (Lim, 2005:170) into something more pluralistic. Lim also appreciates the effort of theater companies (e.g., The Theatre Practice, The Necessary Stage, Theatre Works, and The Third Stage) that have consistently lived up to their mission of creating innovative theater that is focused on indigenous culture that touches heart and mind. Their works reflect a concern with cultural negotiation and artistic exchanges (Lim, 2005: 208209). Those companies allow people from all ethnic groups to make the city livable and the city more vibrant. Additionally, based on the socially meaningful public spaces perspective where the city welcomes all show their cultural heritage and creation, Ling (2004:107) supports the negotiation of differences as opposed to simply ignoring those differences. He points out that cultural, social and economic differences need to be negotiated because a global city is the site of multiculturalism. According to Lim, Ling, and Chong, the cultural policy of Singapore in the future, as what the global cities in the age of migration do, should welcome and anticipate the process of transnational and global culture exchanges and provide spaces for multiethnic and multi-talented people.

\section{Conclusions and Recommendations}

After analyzing the cultural identity of Singapore and state policy that promotes Asian Values borne out of Confucian ethics, I offer three recommendations for Singapore in the future: the citizen's must own the rights to the city, there must be civic spaces for vernacular culture, and there must be a cultural policy that supports the integration of multiculturalism.

\section{Citizens' Rights for the City}

A new cultural policy in building the cultural identity of Singapore as a global city that gives opportunities to all sections of ethnic groups is very important. This policy transforms the mono-cultural interpretation of state hegemony (as championed by the implementation of neo-Confucian Ethics) into a multicultural

Int.J. Hum. Soc. Dev. Res.

Volume 1, № 1, 2017.41-54 
society. The policy offered here emphasizes the diversity of culture that has long existed since British colonial time. It not only highlights the attractiveness and uniqueness of Singapore society, but also supports the nature of heritage. Singaporean society is inherited from the extension of a plural society that consists of AngloSaxon, the Straits of Malacca Babas, Hokkiens, Hakkas, Cantonese, Hainanese, Arabs, Indians, Malays, Orang Laut, Portuguese, and others. The policy facilitates an atmosphere that embraces all the ethnic and sub-ethnic communities to use their rights to shape the cultural identity of Singapore in the process of becoming interconnected with other global societies. Singapore should create a policy that manages all the cultural sections regardless of their political or economic interests. For example, the repressive policy that caused The Third Stage Theater director to be sent to jail based on Internal Security Act (ISA) in 1987 and also banned a Tamil movie Talaq in 1999 should be replaced by a new policy that facilitates the creation of space for ethnic groups.

A strict censorship system excludes the non-mainstream and young generation expressions that the current government considers threatening to the stability of political and economic growth.

\section{Civic Spaces Based on Community}

My second recommendation is to create a cultural policy based on communities that supports a livable global city by emphasizing the local living tradition. The core of this policy is related to the idea that each group of citizens sustains their living tradition and improves and adjusts it with new technology and knowledge. The main reason why this policy would be implemented would be to celebrate the diversity of the multicultural society in Singapore. Social awareness and government responsibility of government is to provide spaces for vernacular cultures. For several decades, the state policy has accommodated a large middle class and has resulted in substantial economic benefits. As a result, the vernacular cultures do not have spaces. A new policy starts from the collective imagination of people, not from the state hegemony and political instrument. As a collective site, this kind of cultural policy facilitates citizens from different ethnic groups to naturalize the function of culture not only for global economic orientation, but also for community building. The policy that sustains the vernacular cultures and will create a young generation that has the capability to reinterpret their own traditions. 
3. Integrating Cultural Policy for Multiculturalism

The purpose of an integrated policy is to recapture humanity and to motivate the attachment of collective memory, social justice, the environment, and future factors to cultural identity. Obligations of city planners to address the ethical and social justice proportionally are urgently needed. This policy emphasizes the new notion of spatial justice in urban planning. The global culture of consumerism and the domination of the state in shaping urban life ignore the integrative policy. This policy tries to reduce the fragmentation of society and spatial polarization by looking at a variety of human cultures and expressions. Singapore should listen to and evaluate the neo-Development model. This policy also tries to unify the expectation of a Singaporean urban planner, William Lim (2005) with recognition of the various levels of society. The policy also captures a number of ideas to create a livable global city that possesses different values, discourses, and local peculiarities. From a postcolonial viewpoint, an integrative cultural policy proposed here, for example, mediates the tensions between local communities and civil servants or government in which dialogues and negotiations ultimately important factors.

\section{Disclosure statement}

No potential conflict of interest was reported by the author.

\section{Contact Information}

E-mail: sam.matondang@yahoo.com 


\section{References and notes:}

Abrahamson, Mark. 2004. Global Cities. New York: Oxford University Press.

Chin-keong, Ng. 1992. "The Cultural Horizon of South China's Emigrants in the nineteenth Century: Change and Persistence." Pp. < put page numbers here $>$ in Asian Traditions and Modernization: Perspectives from Singapore, edited by Young Mun Cheong, Center for Advance Studies, NUS.

Chong, Alan, 2007. "Singapore's Political Economy, 1997-2007: Strategizing Economic Assurance for Globalization." Asian Survey 47(6):

Chong, Terence. 2011.The Theatre and the State in Singapore: Orthodoxy and Resistance. London: Routledge.

Clammer, John. 1998. Race and State in Independent Singapore 1965-1990: The Cultural Politics of Pluralism in a Multiethnic Society. Vermont: Ashgate Publishing Company.

Dales, Johan 1999. Urban Planning in Singapore, the Transformation of a City, London: Oxford University Press.

Douglass, Mike. 2009. "Globopolis or Cosmopolis? - Alternative Futures of City Life in East Asia”, Journal of Urban Humanities

Gertler, Meric S. 1997. "Between the Global and the local, the spatial limits to productivity capital." Pp. < put page numbers here> in Spaces of Globalization: reasserting the power of the local, edited by Kevin R Cox. New York: The Guilford Press

Goh, Daniel P. S. 2009. Race and Multiculturalism in Malaysia and Singapore, London: Routledge

Hui, Ong Jie, at all. 1997. Understanding Singapore Society. Singapore: Times Academic Press

Kearney, A. T. 2010. "Global Cities Index Ranks New York, London, Tokyo and Paris as top Global Cities," The Chicago Council on Global Affairs, and Foreign Policy, October 4

King, Anthony. 2007. Spaces of Global Cultures, Architecture Urbanism Identity. Routledge: London.

Koh, Ai Tee, Lim K Lian, Weng Tat Hui,, Bhanoji Rao, and Chng Meng Kng. 2002. Singapore Economy in the 21th century. Singapore:McGraw Hill.

Kong, Lily. 2007. Cultural icons and urban development in Asia: Economic imperative, national identity. Political Geography 26

McCharty, Stephen. 2006. The Political Theory of Tyranny in Singapore and Burma: Aristotle and Rhetoric benevolent despotism. London: Routledge.

Lim, William S.W. 2005. Asian Ethical Urbanism: A Radical Postmodern Perspective. Singapore: World Scientific Publishing Copie.

Ling, Ooi Giok. 2004. Future of Space: Planning, Space, and the City. Singapore: Marshall Cavendish.

Olds, Kris and Henry Wai-Chung Yeung. 2004. "Pathways to Global City Formation: A View from the Developmental City-State of Singapore", Review of International Political Economy, $11 / 3$

Poon, Angelia. 2009. "Pick and mix for a global city:race and cosmopolitan in Singapore." Pp. <insert page numbers here> in Race and Multiculturalism in Malaysia and Singapore, edited by Daniel PS Goh, London: Routledge

Sassen, $\quad$ Saskia. 2000.2 The Global City:

StrategicSite/NewFrontier,journals.ku.edu/amerstud/2000 
Sassen, Saskia. 2001. The Global City, New York, London, Tokyo (second edition). New Jersey: Princeton University Press.

Sassen, Saskia. 2002. Global Networks, Linked Cities. New York, Routledge

Taylor, Peter J., D.R. F. Walker, and J. V. Beaverstock. 2002. "Firms, and their Global Service Networks." Pp. <insert page numbers here>, in Global Networks, Linked Cities, edited by Saskia Sassen. New York, Routledge

Schmidt, Vivien A. 1999. "Convergent pressures, divergent responses, France, Great Britain, and Germany between globalization and Europeanization." Pp. 173-<insert other page number here>, in States and Sovereignty in the Global Economy, edited by, in David A Smith <and list the other editors as well; et al. doesn't work here>. London: Routledge.

Vasil, Raj. 1995. Asianizing Singapore. Heinemann Asia: Singapore.

Vale, Lawrence J. 1992. Architecture, Power, and National Identity. New York: Routledge.

Velayutham, Selvaraj. 2007. Responding to Globalization: Nation, Culture, and Identity in Singapore. ISEAS: Singapore.

Yah, Lim Chong. 2009. "Transformation in Singapore Economy: course and cases." Pp. <insert page numbers here>, in Singapore and Asia in a Globalized World, Contemporary Economic Issues and Practice, edited by Chia W Mun, and Sng Hui Ying. Singapore: World Scientific.

Yun, Hing Ai. 2001. "Reconstituting the Middle Classes: Teachers, the Evaluative State and the Market in Singapore." Pp. <insert page numbers here>, in Southeast Asian Middle Classes, Prospects for Social Change and Democratisation, edited by in Abdul R Ambong. Kuala Lumpur: Universiti Kebangsaan Malaysia

Washington Post, 2001, Newsweek Interactive, LLC, Measuring Globalization, Foreign Policy, No. 122 (Jan. - Feb), p. 57 